\title{
Traditional Chinese Medicine and herbal hepatotoxicity: a tabular compilation of reported cases
}

\author{
Rolf Teschke, ${ }^{*}$ Li Zhang, ${ }^{\dagger}$ Hongzhu Long, ${ }^{\ddagger}$ Alexander Schwarzenboeck, ${ }^{*}$ Wolfgang Schmidt-Taenzer, ${ }^{*}$ \\ Alexander Genthner, ${ }^{*}$ Albrecht Wolff, ${ }^{\S}$ Christian Frenzel, " Johannes Schulze, " Axel Eickhoff* \\ *Department of Internal Medicine II, Division of Gastroenterology and Hepatology, Klinikum Hanau, \\ Teaching Hospital of the Medical Faculty of the Goethe University Frankfurt/ Main, Germany. \\ tCenter for Drug Reevaluation, China Food and Drug Administration, Beijing, China. \\ ‡Department of Internal Medicine, Dongfang Hospital, Beijing University of Chinese Medicine, Beijing, China. \\ §Department of Internal Medicine II, Division of Gastroenterology, Hepatology and Infectious Diseases, Friedrich Schiller University Jena, Germany. \\ IDepartment of Medicine I, University Medical Center Hamburg Eppendorf, Germany. \\ IInstitute of Industrial, Environmental and Social Medicine, Medical Faculty of the Goethe University Frankfurt/Main, Germany.
}

\section{ABSTRACT}

Traditional Chinese Medicine (TCM) with its focus on herbal use became popular worldwide. Treatment was perceived as safe, with neglect of rare adverse reactions including liver injury. To compile worldwide cases of liver injury by herbal TCM, we undertook a selective literature search in the PubMed database and searched for the items Traditional Chinese Medicine, TCM, Traditional Asian Medicine, and Traditional Oriental Medicine, also combined with the terms herbal hepatotoxicity or herb induced liver injury. The search focused primarily on English-language case reports, case series, and clinical reviews. We identified reported hepatotoxicity cases in 77 relevant publications with 57 different herbs and herbal mixtures of TCM, which were further analyzed for causality by the Council for International Organizations of Medical Sciences (CIOMS) scale, positive reexposure test results, or both. Causality was established for 28/57 different herbs or herbal mixtures, Bai Xian Pi, Bo He, Ci Wu Jia, Chuan Lian Zi, Da Huang, Gan Cao, Ge Gen, Ho Shou Wu, Huang Qin, Hwang Geun Cho, Ji Gu Cao, Ji Xue Cao, Jin Bu Huan, Jue Ming Zi, Jiguja, Kudzu, Ling Yang Qing Fei Keli, Lu Cha, Rhen Shen, Ma Huang, Shou Wu Pian, Shan Chi, Shen Min, Syo Saiko To, Xiao Chai Hu Tang, Yin Chen Hao, Zexie, and Zhen Chu Cao. In conclusion, this compilation of liver injury cases establishes causality for 28/57 different TCM herbs and herbal mixtures, aiding diagnosis for physicians who care for patients with liver disease possibly related to herbal TCM.

Key words. Herb induced liver injury. Council for International Organizations of Medical Sciences. Herbs. Causality assessment. Re-exposure.

\section{INTRODUCTION}

Traditional Chinese Medicine (TCM) and in particular its herbal sector is popular in $\mathrm{China}^{1}$ and many countries worldwide. ${ }^{2-4}$ For most traditional herbal treatments, there is insufficient rigorous scientific evidence about the efficiency of herbal TCM

Correspondence and reprint request: Rolf Teschke, M.D.

Professor of Medicine. Department of Internal Medicine II.

Klinikum Hanau, Academic Teaching Hospital of the Goethe University of Frankfurt/Main

Leimenstrasse 20, D-63450 Hanau, Germany

Tel.: +49-6181/21859

E-mail: rolf.teschke@gmx.de

Manuscript received: July 17, 2014. Manuscript accepted: August 25, 2014. for their claimed indications, ${ }^{3}$ usually due to lack of research publications in English. Consequently, additional controlled clinical trials are needed to evaluate their efficacy and risk profile including scientific publications, preferentially in English. ${ }^{5}$ In Western countries, herbal TCM is considered as natural and erroneously thereby assumed to be safe, delaying recognition of possible side effects and timely treatment discontinuation. Although side effects by herbal TCM in general are rare and mostly transient upon treatment cessation, hepatic adverse reactions may be life threatening, requiring a liver transplant, or both. ${ }^{6-8}$

This concise article presents for the first time a comprehensive tabular compilation of all potentially hepatotoxic herbal TCMs. These are individually identified by respective references published since 
1986. Additional information is provided for the names of the authors, the year of publication, and the overall number of reported cases. Other tabular compilations present results of individual causality assessments by liver specific algorithms and positive reexposure test results.

\section{LITERATURE SEARCH}

To collect all cases of liver injury by herbal TCM, a selective literature search in the PubMed database was performed. We used the search items Traditional Chinese Medicine, TCM, Traditional Asian Medicine, and Traditional Oriental Medicine alone and combined with the terms herbal hepatotoxicity, or herb induced liver injury.

The search was primarily focused on English-language case reports, case series, and clinical reviews, published from 1984 to $15 \mathrm{March}, 2014$. From each search, the first 25 publications being the most relevant publications were analyzed for subject matter, data quality, and overall suitability. All citations in these publications were searched for other yet unidentified case reports.

\section{TRADITIONAL CHINESE MEDICINE}

TCM is no single entity but encompasses different practices including acupuncture, moxibustion, massage, dietary therapy, and physical exercise such as shadow boxing, with herbal medicines as the most important section. ${ }^{1-3}$ In Western countries, the use of the name TCM remained unchanged, in recognition of the tradition originating from ancient China. Therefore, we used the term Traditional Chinese Medicine (TCM) pragmatically as a general term since a regional differentiation would introduce unwanted selection bias effects unrelated to the herbal ingredients. TCM in this review therefore combines Traditional Asian Medicine (TAM), Traditional Oriental Medicine (TOM), Traditional Korean Medicine (TKM), and Traditional Kampo Medicine (TKM) since the principles are identical or vary little between countries. Using TCM as the generic term facilitates and focuses discussions of TCM related issues.

\section{COMPILATION OF RELEVANT CASES}

We identified 57 different herbs and herbal mixtures of TCM with potential liver injury in 77 case reports and case series (Table 1); their clinical case details were presented earlier. ${ }^{9-87}$ Such a detailed compilation of cases has not been published before and it may assist clinicians and practitioners evaluating patients with suspected hepatotoxicity by the use of herbal TCM. Three additional reports of hepatotoxicity cases following herbal TCM use were excluded from table 1 because details of the applied herbs were missing. ${ }^{88-90}$ The figure of 57 different herbs and herbal mixtures compares with 582 medicinal herbs of the Chinese Materia Medica (CMM), which are available in China and are officially recognized and described in detail by the Chinese Pharmacopeia. ${ }^{91,92}$ If all herbs of widespread use, regional variations, and folk medicine are included, then the total increases to around 13,000 CMM preparations currently in use in China. ${ }^{91,93}$ Since our review is based on English language case reports, many more than the presently 57 different herbs and herbal mixtures of TCM with potential hepatotoxicity likely exist. This implies that reports in Chinese or other languages are not included, as they are difficult to locate, difficult to evaluate due to language barriers, and difficult to reassess. Nevertheless, a few abstracts have been included in our analysis, if provided in English and considered essential. Consequently, our analysis facilitates wide accessibility and promotes reevaluation but likely covers only a minority of the truly existing cases.

Botanical names of herbs are provided, which were used individually or as combination partners of herbal mixtures (Table 1). These names were retrieved from the published reports and verified through an internet search. The herbs were not always further specified, because relevant data often were contradictory and insufficiently described in the publications. One TCM name may be used for various preparations in China, but not necessarily in other countries. Among these are prepared decoction pieces (known as Yin Pian), extracts or granules of the decoction pieces (known as Keli), as well as unprepared and crude material. ${ }^{1}$ Of particular importance are Proprietary Chinese Medicines (PCM) products known as Zhong Cheng Yao, which must be approved by the China FDA before marketing. ${ }^{1}$ Unapproved PCM products are regarded illegal medicines and are commonly of poor quality, shortcomings likely applying to other countries as well.

The reference list for the reports mentioned in table 1 allows information for number and period of publication. In the years 1984 to 1993,1994 to 2003, and 2004 to 2013 , there were 2,20 , and 55 publications for the respective periods. With 28 and 27 publications for 2004 to 2008 and for 2009 to 2013, the publication frequency was stable within the last decade. Hepato- 
Table 1. Compilation of reported cases with suspected hepatotoxicity by herbal Traditional Chinese Medicine.

Name with ingredients
An Shu Ling Lycopodium serratum or, rarely, Corydalis species,
Panax ginseng, Pseudo ginseng, or two species of Stephania
Bai Fang Angelica sinensis, Cyperus rotundus, Ginseng, Ligusticum wallich
Paeonia alba, Rehmannia glutinosa
Bai Shi Wan Atractylis, Carthamus tinctorius, Dalbergia odorifera,
Dioscorea bulbifera, Glycyrrhiza, Lithospermum erythrorhizon,
Paeonia suffruticosa, Polygonum multiflorum, Psoralea corylifolia,
Salvia miltiorrhiza; Endoconcha sepiae, Ganoderma lucidum (mushroom)

Bai Xian Pi Dictamnus dasycarpus

Ban Tu Wan Angelica sinensis, Chaenomeles, Codonopsis pilosula, Notopterygium, Polygonum multiflorum, Rehmannia, Schisandra Bo He Mentha haplocalyx

Bo Ye Qing Niu Dan Tinospora crispa

Bofu Tsu Sho San Angelica, Atractylis, Cnidium, Gardenia, Ephedra, Forsythia, Glycyrrhhiza, Gypsum fibrosum, Ledebouriella, Mentha, Paeonia, Platycodon, Rheum, Schizonepeta, Scutellaria, Zingiber; Kadinum (talcum powder), sodium sulfuricum

Boh Gol Zhee Psoralea corylifolia

Cang Er Zi Xanthium sibiricum

Chai Hu Bupleurum falcatum

Chaso Camellia sinensis, Cassia tora (syn. Senna), Crataegus,

Chrysanthenum morifolium Ramat., Lotus, Lycium barbarum;

$\mathrm{N}$-nitroso-fenfluramine

Chi R Yun Breynia officinalis

Chinese herbal mixtures (various) Dictamnus dasycarpus, Gentiana scabra, Hedyotis diffusa, Paeonia suffructicosa, Paris polyphylla, Rehmannia glutinosa, Smilax glabra, Sophora subprostrata;

Angelica sinensis, Bupleurum chinese, Dictamnus dasycarpus,

Paeonia suffructiosa, Philodendron chinese, Saposhnikovia divaricata,

Shisandra chinesis, Shizonepeta tenuifolia, Tribulus terrestris;

Cocculus trilobus, Dictamnus dasycarpus, Eurysolen gracilis, Glycyrrhiza,

Lophatherum, Paeonia, Potentilla, Rehmannia glutinosa;

Alisma plantago aquatica, Artemisia capillaris, Bupleurum,

Chrysanthemum morifolium, Circuma, Gardenia jasminoidis,

Gentiana scabra, Glycyrrhiza, Magnolia, Paeonia, Plantago asiatica,

Saussurea lappa

Chuan Lian Zi Melia toosendan

Ci Wu Jia Acanthopanax senticosus

Da Chai Hu Tang Bupleurum falcatum, Ginseng, Glycyrrhiza glabra, Pinellia, Scutellaria, Zingiber officinale, Zizyphus jujuba

Da Huang Rheum palmatum

Du Huo Angelica archangelica

Fu Fang Qing Dai Wan Angelica dahurica, Isatis indigotica (Indigo naturalis),

Cases (n) References

1

1

1
Haller, et al., $2002^{9}$

Estes, et al., $2003^{10}$

Talari, et al., $2010^{11}$

Perharic-Walton/Murray, $1992^{12}$ Kane, et al., $1995^{13}$

Vautier/Spiller, $1995^{14}$ Yuen, et al., $2006^{15}$ Jang, et al., $2008^{16}$ Kang, et al., $2008^{17}$ Sohn, et al., $2008^{18}$

Cortez, et al., $2012^{19}$

Sangsuwan, et al., $2004^{20}$

Motoyama, et al., $2008^{21}$

Hwang, et al., $2001^{22}$

Nam, et al., $2005^{23}$

Cheung, et al., $2009^{24}$

Chau, $2008^{25}$

Lee, et al., $2011^{26}$

Adachi, et al., $2003^{27}$

Lin, et al., 2002; 28

Lin, et al., $2003^{29}$

Perharic-Walton/Murray, $1992^{12}$

Kane, et al., $1995^{13}$

Vautier/Spiller, $1995^{14}$

Yoshida, et al., $1996^{30}$

Yuen, et al., $2006^{15}$

Sohn, et al., $2008^{17}$

Kamiyama, et al., $1997^{31}$

Yuen, et al., $2006^{15}$

Björnsson, et al., 201332

Verucci, et al., $2002^{33}$ 
Massa medicata fermentata (yeast), Salvia milthiorrhiza, Smilax glabra

Gan Cao Glycyrrhiza uralensis, syn. Liquorice

Ge Gen Pueraria lobata, syn. Arrowroot

Ho Shou Wu Polygonum multiflorum, syn. He Shou Wu

Hu Bohe You Mentha pulegium, syn. Pennyroyal oil

Hu Zhang Polygonum cuspidatum

Huang Qin Scutellaria baicalensis

Huang Yao Zi Dioscorea bulbifera

Hwang Geun Cho Corydalis speciosa

15Ji Gu Cao Abrus cantoniensis

Ji Ji Chloranthus serratus

Ji Xue Cao Centella asiatica, syn. Gotu Kola

Jiguja Hovenia dulcis

Jin Bu Huan Lycopodium serratum or, rarely, Corydalis species, Panax ginseng, Pseudo ginseng, or two species of Stephania

Jue Ming Zi Cassia obtusifolia, syn. Senna obtusifolia

Kamishoyosan Angelica sinensis, Atractylodes racea, Bupleurum falcatum, Gardenia, Glycyrrhiza glabra, Mentha haplocalyx, Moutan, Paeonia alba, Sclerotium Poriae Cocos, Zingiber officinale

Kudzu Pueraria thunbergiana

Lei Gong Teng Tripterygium wilfordii Hook

Long Dan Xie Gan Tang Acebia, Alisma, Angelica sinensis, Bupleurum, Gardenia, Gentiana, Glycyrrhiza, Plantago, Rehmannia, Scutellaria

Lu Cha Camellia sinensis, syn. Chinese green tea

Ma Huang Ephedra sinica

Mao Guo Tian Jie Cai Heliotropium lasiocarpum

Onshido Aloe, Camellia sinensis, Crataegus,
Yuen, et al., $2006^{15}$

Kim, et al., $2009^{34}$

Yuen, et al., $2006^{15}$

Bae, et al., $2010^{35}$

Chau, $2008^{25}$

Chau, $2008^{25}$

Gono, et al., $2010^{36}$

Linnebur, et al., $2010^{37}$

Yang, et al., $2012^{38}$

Dhanasekaran, et al., $2013^{39}$

Chau, 2008 25

Kang, et al., $2009^{40}$

Yuen, et al., $2006^{15}$

Chau, $2008^{25}$

Jorge/Jorge, $2005^{41}$

Sohn, et al., $2008^{18}$

Kang, et al., $2008^{17}$

Kim, et al., $2012^{42}$

Woolf, et al., 199443

Horowitz, et al., $1996^{44}$

Picciotti, et al., $1998^{45}$

Divinsky, $2002^{46}$

Haller, et al., $2002^{9}$

Yuen, et al., $2006^{15}$

Inoe, et al., $2011^{47}$

Kang, et al., $2008^{17}$

Chau, $2008^{25}$

Lee, et al., $2011^{26}$

Garcia-Moran, et al., $2004^{48}$

Peyrin-Biroulet, et al., $2004^{49}$

Gloro, et al., $2005^{50}$

Javaid/Bonkovsky, $2006^{51}$

Jimenez-Saenz, et al., $2006^{52}$

Bonkovsky, $2006^{53}$

Molinari, et al., $2006^{54}$

Björnsson/Olsson, $2007^{55}$

García-Cortés, et al., $2008^{56}$

Sarma, et al., $2008^{57}$

Mazzanti, et al., 200958

Rohde, et al., $2011^{59}$

Navarro, et al., $2013^{60}$

Nadir, et al.199661

Borum, 200162

Estes, et al., $2003^{10}$

Skoulidis, et al., $2005^{63}$

Reuben, et al., $2010^{64}$

Culvenor, et al., $1986^{65}$

Adachi, et al., $2003^{27}$ 
Gynostemma pentaphyllum makino, Raphanus; N-nitroso-fenfluramine

Qian Li Guang Senecio scandens

Ren Shen Panax ginseng

Sairei To Alisma, Atractylis, Bupleurum, Cinnamomum, Ginseng, Glycyrrhiza, Pinellia, Polyporus, Poria, Scutellaria, Zingiber, Zizyphus

Shan Chi Gynura segetum

Shen Min Black cohosh, Burdock, Cayenne pepper, Ginkgo biloba, Horse chestnut, Piper nigrum, Polygonum multiflorum, uva ursi; biotin, collagen (hydrolyzed), niacin, pantothenic acid, silica (from plant sources), soy isoflavones, vitamin $A$, vitamin $B_{6}$

Shi Can Teucrium chamaedrys, syn. Germander

Shi Liu Pi Pericarpium granati

Shou Wu Pian Achyranthes bidentata, Cuscuta chinensis, Eclipta prostrata, Ligustrum lucidum, Lonicera japonica, Morus alba, Polygonum multiflorum, Psoralea corylifolia, Rehmannia glutinosa, Rosa laevigata, Sesemum indicum, Siegesbeckia orientalis

\section{Tian Hua Fen Trichosanthes kirilowii}

White flood Qian Ceng Ta (Huperzia serrata), Wu Zhu Yu (Evodia rutaecarpa); beet root, caffein, cocoa bean, vinpocetine (from Vinca plant); acesulfame potassium, calcium silicate, carnitine tartrate, Carno-Syn $₫$ beta-alanine, citrulline, cryptoxanthin, folic acid, gamma-aminobutyric acid (GABA), glucuronolactone, selenium, L-norvaline, L-tyrosine, lutein, malic acid, ornithine, potassium gluconate, sucralose, sugar cane, watermelon flavor, zeaxanthin

Wu Bei Zi Galla chinensis

Xi Shu Camptotheca acuminata

Xiao Chai Hu Tang Bupleurum falcatum, Ginseng, Glycyrrhiza glabra, Pinellia tuber, Scutellaria baicalensis, Zingiber officinale, Zizyphus jujuba

Yin Chen Hao Artemisia capillaris

Zexie Alisma orientalis

Zhen Chu Cao Phyllanthus urinaria
Chau, $2008^{25}$

Kang, et al., $2008^{17}$

Aiba, et al., $2007^{66}$

Tsuda, et al., $2010^{67}$

Dai, et al., $2006^{68}$

Chen, et al., 200769

$\mathrm{Li}$, et al., $2010^{70}$

Lin, et al., $2011^{71}$

Gao, et al., 2012 72

Cárdenas, et al., $2006^{73}$

Chau, $2008^{25}$

Chau, $2008^{25}$

But, et al., $1996^{74}$

Park, et al., 200175

Battinelli, et al., 200476

Panis, et al., $2005^{77}$

Sohn, et al., $2008^{18}$

Laird, et al., $2008^{78}$

Furukawa, et al., 2010 79

Valente, et al., $2010^{80}$

Jung, et al., $2011^{81}$

Banarova, et al., $2012^{82}$

na Chau, 200825

Cohen, et al., $2012^{83}$

Data are retrieved from a selective literature search for published cases of herbal TCM associated with suspected hepatotoxicity. In some cases, causality for individual herbs and herbal mixtures was established using the Council for International Organizations of Medical Sciences (CIOMS) scale or its modifications, and by positive reexposure test results. For other cases, information was fragmentary and did not necessarily allow a firm causal attribution. Details are provided by the original reports referenced above and by other articles. ${ }^{86,87}$

toxicity by herbal TCM is reported from many countries around the world with various publications ${ }^{9-90}$ from China, 4; Hong Kong, 5; Taiwan, 4; Japan, 9; Korea, 10; Thailand, 1; Australia, 2; Slovakia, 1; Italy, 5; Spain, 3; France, 2; the Netherlands, 1; the
United Kingdom, 4; Denmark, 1; Iceland, 2; Canada, 2; the United States, 20; and Argentina, 1.

Herbal hepatotoxicity is not limited to herbal TCM but also occurs worldwide with numerous other herbs. ${ }^{7,8}$ Among sixty different herbs or herbal 
mixtures with hepatotoxic potential identified in a recent study, which analyzed 185 published reports, only few were TCM herbs. ${ }^{7}$ Overt differences of hepatotoxicity between TCM herbs and non TCM herbs are lacking in clinical presentation, types of liver injury, latency period, dechallenge characteristics, and reexposure characteristics, when comparing the original publications for the present analysis (9-85) with those of the previous publications. ${ }^{7,8}$ Both groups have a similar incidence of severity, liver transplantation, and lethal outcome.

\section{CAUSALITY ASSESSMENT}

In patients with suspected herbal liver injury by TCM, the key question is the diagnostic validity. Hepatotoxicity requires strict criteria, best defined by alanine aminotransferase (ALT) and/or alkaline phosphatase (ALP) values. ${ }^{94,95}$ Its increase is converted into multiples of the upper limit of their normal range, given as N. For ALT, hepatotoxicity has been defined as increases of $>2 \mathrm{~N},>3 \mathrm{~N}$ or $>5 \mathrm{~N}$, while ALP values of $>2 \mathrm{~N}$ are commonly considered diagnostic. ${ }^{96,97}$ Restricting only ALT increases of $>5 \mathrm{~N}$ as diagnostic eliminates false positive cases and substantiates causality at a higher level of probability. Considering ALT $>2 \mathrm{~N}$ as hepatotoxic will include numerous patients with nonspecific increases, with higher requirements for thorough assessment and more stringent exclusion of causes unrelated to the herb(s) under discussion. Also for low threshold $\mathrm{N}$ values, more diagnostic alternatives must be ruled out; missing an exclusion of a hepatotoxicity case results in overdiagnosing and overreporting with false high case numbers ${ }^{96}$ Commonly an ALT cutoff point of $5 \mathrm{~N}$ is used, or an ALT cutoff of $3 \mathrm{~N}$ if the total bilirubin exceeds $2 \mathrm{~N}$; for ALP, $2 \mathrm{~N}$ is considered an appropriate definition criterion. ${ }^{96,97}$ These criteria are likely fulfilled by most reports included in this review, even considering that $\mathrm{N}$ values are rarely mentioned, and some publications do not mention any liver values at all. ${ }^{9-85}$ Applying these criteria, the herbal TCM Ba Jiao Lian (Dysosma pleianthum) was not proven hepatotoxic, although this was initially assumed. ${ }^{86,98}$ Therefore, Ba Jiao Lian is not included as a hepatotoxin in this review of TCM. Valid diagnostic biomarkers in patients with suspected herbal hepatotoxicity currently are lacking, ${ }^{8}$ except for pyrrolizidine alkaloids (PAs) where quantification of protein adducts and GSH conjugates in the blood allows intake quantification. ${ }^{72,86}$ Considering these limitations and the need of early evaluation of suspicious cases, the best approach for quick assessment is the combination of clinical judgement and a liver specific causality assessment algorithm like the scale of CIOMS (Council for International Organizations of Medical Sciences), also called RUCAM (Roussel Uclaf Causality Assessment Method). ${ }^{94,95}$ This CIOMS scale has been used in cases of herbal TCM hepatotoxicity and commonly provides high quality classifications of highly probable and probable cases initially (Table 2) or after reassessment. ${ }^{99}$ In some cases, a previous CIOMS version ${ }^{100}$ or a modified CIOMS version $^{101}$ was used for assessment (Table 2). Although commonly recommended, ${ }^{102}$ overall CIOMS based evaluations were done in only 18 reports (Table 2), not in the remaining 59 publications analyzed in the present review (Table 1). In the future, therefore, all suspected cases should undergo CIOMS assessment to improve case data evaluation.

\section{REEXPOSURE}

A positive reexposure test result commonly is considered as the gold standard to verify the diagnosis of herb induced liver injury. ${ }^{86,99,103}$ Since reexposure tests are unintentional and therefore not planned in advance, these cases also have to be analyzed in retrospect. Consequently, under these circumstances case data often are of poor quality, lacking basic criteria for a positive test result. In 25 cases of suspected herbal TCM hepatotoxicity, the authors claimed a positive reexposure test (Table 3); however, in only 14 cases this result was confirmed upon reassessment, when specific and accepted criteria were applied (Table 3) ${ }^{86,99}$ In the remaining nine patients, the evaluation was either negative or uninterpretable. Intentional reexposure tests are unethical and obsolete due to high risks.

\section{CAUSALITY VERIFICATION}

Among the reported cases of herbal hepatotoxicity (Table 1), causality was verified by CIOMS scale grades, positive reexposure tests, or both for 27 different herbs and herbal mixtures (Tables 2 and 3 ), out of a total of 57 (Table 1). These included Bai Xian Pi, Bo He, Ci Wu Jia, Chuan Lian Zi, Da Huang, Gan Cao, Ge Gen, Ho Shou Wu, Huang Qin, Hwang Geun Cho, Ji Gu Cao, Ji Xue Cao, Jin Bu Huan, Jue Ming Zi, Juguja, Kudzu, Ling Yang Qing Fei Keli, Lu Cha, Rhen Shen, Ma Huang, Shou Wu Pian, Shan Chi, Shen Min, Syo Saiko To, Xiao Chai Hu Tang, Yin Chen Hao, Zexie, and Zhen Chu Cao. Causality was also established in two un- 
Table 2. Reported causality assessment by the CIOMS (Council for International Organizations of Medical Sciences) scale in cases of assumed herbal hepatotoxicity by Traditional Chinese Medicine.

\begin{tabular}{|c|c|c|c|}
\hline Product name & CIOMS causality gradings & CIOMS scores & Cases $(n)$ \\
\hline Bai Xian Pi & $\begin{array}{l}\text { Probable } \\
\text { na }\end{array}$ & $\begin{array}{l}6-8 \\
\text { na }\end{array}$ & $\begin{array}{l}2^{18} \\
14^{17}\end{array}$ \\
\hline Bo He & Probable & $6-8$ & $1^{15}$ \\
\hline Chinese herbal mixtures & $\begin{array}{l}\text { Probable } \\
\text { Possible } \\
\text { Excluded }\end{array}$ & $\begin{array}{l}8 \\
5 \\
-1\end{array}$ & $\begin{array}{l}188,99 \\
112,99 \\
116,99\end{array}$ \\
\hline Ci Wu Jia & $\begin{array}{l}\text { Probable } \\
\text { Possible }\end{array}$ & $\begin{array}{l}6-8 \\
3-5\end{array}$ & $\begin{array}{l}1^{18} \\
1^{18}\end{array}$ \\
\hline Chuan Lian Zi & Highly probable & $>8$ & $1^{15}$ \\
\hline Da Huang & Highly probable & $>8$ & $1^{15}$ \\
\hline Gan Cao & Probable & $6-8$ & $1^{15}$ \\
\hline Ge Gen & Highly probable & 10 & $2^{34}$ \\
\hline Ho Shou Wu & $\begin{array}{l}\text { Highly probable } \\
\text { Highly probable }\end{array}$ & $\begin{array}{l}>8 \\
10\end{array}$ & $\begin{array}{l}115 \\
135\end{array}$ \\
\hline Huang Qin & Possible & 5 & $1^{38,99}$ \\
\hline Ji Gu Cao & Possible & 3-5 & $1^{15}$ \\
\hline Ji Xue Cao & na & na & $3^{41}$ \\
\hline Jin Bu Huan & $\begin{array}{l}\text { Probable } \\
\text { Probable } \\
\text { Possible }\end{array}$ & $\begin{array}{l}8 \\
6 \\
4\end{array}$ & $\begin{array}{l}2^{43,99} \\
1^{44,99} \\
1^{44,99}\end{array}$ \\
\hline Jue Ming Zi & Highly probable & $>8$ & $1^{15}$ \\
\hline Juguja & $\begin{array}{l}\text { Probable } \\
\text { Possible }\end{array}$ & $\begin{array}{l}6 \\
3-5\end{array}$ & $\begin{array}{l}142 \\
1^{18}\end{array}$ \\
\hline Kudzu & na & na & $6^{17}$ \\
\hline $\begin{array}{l}\text { Ling Yang } \\
\text { Qing Fei Keli }\end{array}$ & Probable & $6-8$ & $1^{15}$ \\
\hline Lu Cha & $\begin{array}{l}\text { Highly probable } \\
\text { Highly probable } \\
\text { Highly probable } \\
\text { Probable } \\
\text { Probable } \\
\text { Probable } \\
\text { Probable } \\
\text { Probable } \\
\text { Possible } \\
\text { na }\end{array}$ & $\begin{array}{l}9 \\
9 \\
>8 \\
8 \\
8 \\
7 \\
6-8 \\
6 \\
3-5 \\
\text { na }\end{array}$ & $\begin{array}{l}149,99 \\
2^{55} \\
2^{56} \\
1^{52,99} \\
2^{55} \\
1^{53,99} \\
1^{56} \\
1^{55} \\
1^{50} \\
6^{17}\end{array}$ \\
\hline Ma Huang & Possible & 4 & $1^{61,99}$ \\
\hline Shou Wu Pian & $\begin{array}{l}\text { Highly probable } \\
\text { Highly probable } \\
\text { Probable } \\
\text { Probable } \\
\text { Possible }\end{array}$ & $\begin{array}{l}>8 \\
>8 \\
6-8 \\
6-8 \\
3-5\end{array}$ & $\begin{array}{l}10^{81} \\
1^{79} \\
15^{81} \\
2^{18} \\
1^{18}\end{array}$ \\
\hline Shan Chi & $\begin{array}{l}\text { Highly probable } \\
\text { Probable } \\
\text { Probable } \\
\text { Possible }\end{array}$ & $\begin{array}{l}9 \\
7 \\
6 \\
5\end{array}$ & $\begin{array}{l}171 \\
2^{72} \\
1^{72} \\
2^{72}\end{array}$ \\
\hline Shen Min & Probable & $6-8$ & $1^{73}$ \\
\hline Syo Saiko To & $\begin{array}{l}\text { Highly probable } \\
\text { Probable } \\
\text { Probable }\end{array}$ & $\begin{array}{l}9 \\
8 \\
6\end{array}$ & $\begin{array}{l}1^{84,99} \\
1^{84,99} \\
2^{84,99}\end{array}$ \\
\hline Yin Chen Hao & $\begin{array}{l}\text { Probable } \\
\text { na }\end{array}$ & $\begin{array}{l}6-8 \\
\text { na }\end{array}$ & $\begin{array}{l}1^{18} \\
7^{17}\end{array}$ \\
\hline Zexie & Highly probable & $>8$ & $1^{15}$ \\
\hline Zhen Chu Cao & Possible & $3-5$ & $1^{15}$ \\
\hline
\end{tabular}

For the listed numbers of cases, the respective publication is provided as superscript. Most listed cases were assessed by the Council for International Organizations of Medical Sciences (CIOMS) scale, ${ }^{94,96}$ single cases by an earlier CIOMS version ${ }^{100}$ or by a modified CIOMS version. ${ }^{101}$ In some original reports, CIOMS causality grading was presented without any individual CIOMS score, so the range of the scores was provided in this table rather than an accurate score number. In one publication of a case series, data of the scores were presented only as means ${ }^{17}$ and therefore classified in the table as not available, since individual scores were not provided. Abbreviation: na, not available. 
Table 3. Causality reassessment of positive reexposure test results initially reported in original publications for cases of herbal hepatotoxicity by Traditional Chinese Medicine.

\begin{tabular}{|c|c|c|c|}
\hline Product name & $\begin{array}{c}\text { Reexposure test } \\
\text { conditions (reassessed) }\end{array}$ & $\begin{array}{l}\text { Test results } \\
\text { (reassessed) }\end{array}$ & Cases (n) \\
\hline Chinese herbal mixtures & $\begin{array}{l}\text { ALTb }<5 \mathrm{~N}, \text { ALTr } \geq 2 \text { ALTb } \\
\text { ALTb and ALTr not available }\end{array}$ & $\begin{array}{l}\text { Positive } \\
\text { Uninterpretable }\end{array}$ & $\begin{array}{l}2^{13,88} \\
1^{12}\end{array}$ \\
\hline Ho Shou Wu & Not assessable & Uninterpretable & $1^{35}$ \\
\hline Hwang Geun Cho & $A L T b<5 N, A L T r \geq 2 A L T b$ & Positive & $1^{17}$ \\
\hline Ji Xue Cao & $\begin{array}{l}\text { ALTb }<5 N, \text { ALTr } \geq 2 A L T b \\
\text { ALTb not available }\end{array}$ & $\begin{array}{l}\text { Positive } \\
\text { Uninterpretable }\end{array}$ & $\begin{array}{l}1^{41} \\
1^{41}\end{array}$ \\
\hline Jin Bu Huan & $\begin{array}{l}\mathrm{ALTb}<5 \mathrm{~N}, \mathrm{ALTr} \geq 2 \mathrm{ALTb} \\
\mathrm{ALTb} \geq 5 \mathrm{~N}, \mathrm{ALTr}<2 \mathrm{ALTb} \\
\mathrm{ALTb}<5 \mathrm{~N} \text { but ALTr }<2 \text { ALTb }\end{array}$ & $\begin{array}{l}\text { Positive } \\
\text { Negative } \\
\text { Negative }\end{array}$ & $\begin{array}{l}2^{43} \\
1^{44} \\
1^{44}\end{array}$ \\
\hline Lu Cha & $\begin{array}{l}\text { ALTb }<5 \mathrm{~N}, \mathrm{ALTr} \geq 2 \mathrm{ALTb} \\
\text { ALTb }<5 \mathrm{~N} \text { but ALTr not available } \\
\text { ALTb and ALTr not available }\end{array}$ & $\begin{array}{l}\text { Positive } \\
\text { Uninterpretable } \\
\text { Uninterpretable }\end{array}$ & $\begin{array}{l}3^{49,52,53} \\
1^{56} \\
2^{56,57}\end{array}$ \\
\hline Ma Huang & ALTb and ALTr not available & Uninterpretable & $1^{61}$ \\
\hline Shou Wu Pian & $\mathrm{ALTb}<5 \mathrm{~N}, \mathrm{ALTr} \geq 2 \mathrm{ALTb}$ & Positive & $2^{77,81}$ \\
\hline $\begin{array}{l}\text { Xiao Chai } \\
\text { Hu Tang }\end{array}$ & $\begin{array}{l}\text { ALTb }<5 \mathrm{~N}, \mathrm{ALTr} \geq 2 \mathrm{ALTb} \\
\mathrm{ALTb}<5 \mathrm{~N} \text { but ALTr }<2 \mathrm{ALTb}\end{array}$ & $\begin{array}{l}\text { Positive } \\
\text { Negative }\end{array}$ & $\begin{array}{l}3^{84} \\
1^{84}\end{array}$ \\
\hline
\end{tabular}

For the llisted numbers of cases, the respective publications are provided as superscripts. Clinical details and laboratory values were obtained from the original reports, which all described a positive reexposure test result without providing specific criteria. For all 25 cases, reassessment of the reexposure test data was done applying established and strict criteria, 86,99 and the reassessed test results are presented in the table. These results showed a positive causality only in 14 cases, without firm causality in nine cases as claimed in the original reports. Criteria for the hepatocellular type of liver injury ${ }^{99,103}$ are the ALT levels at baseline before reexposure (ALTb), and the ALT levels during reexposure (ALTr). Response to reexposure is considered positive if $A L T r \geq 2 A L T b$ and $A L T b<5 N$, with $N$ as the upper limit of the normal value. Other combinations result in negative causality or uninterpretable results.ALT: alanine aminotransferase. $\mathrm{n}$ : upper limit of normal.

classified Chinese herbal mixtures (Table 2), from five mixtures initially included (Table 1).

\section{HERBAL MISIDENTIFICATION, CONTAMINATION, AND ADULTERATION}

It is well recognized that herbal products conform only to fewer quality standards than chemical drugs. ${ }^{7,8,104,105}$ This also applies to most herbal TCM products used worldwide..$^{94,91,106-108}$ In China, strict regulations exist for China FDA approved herbal TCM products, ameliorating this problem. ${ }^{1}$

In the presently analyzed reports, botanical authenticity of individual herbal ingredients mostly was not published, with exceptions related to An Shu Ling, ${ }^{9,86}$ Chi R Yun (Breynia officinalis) and Yi Yi Qiu (Securinega suffruticosa), ${ }^{28,29,68-72,86,109,110} \mathrm{Jin}$ $\mathrm{Bu}$ Huan and Hua Nan Yuan Zhi (Polygala chinen- sis), ${ }^{43,44}$ Shan Qi (Gynura segetum) and Jing Tian San Qi (Sedum aizoon), ${ }^{68-72,86,109,110}$ Shan Qi (Gynura segetum) and Mao Guo Tian Jie Cai (Heliotropium lasiocarpum), ${ }^{65,111,112}$ as well as Shou Wu Pian. ${ }^{74}$ For some herbal TCM products, problems have been identified in misidentification on package insert ${ }^{43,44,60,106}$ including mistaken herb identity, $28,29,44,65,68-72,86,108-113$ and insufficient sample amounts. ${ }^{113}$

Another concern for human use is the possible contamination with dust, pollens, insects, rodents, parasites, microbes, fungi, moulds, toxins, and pesticides. ${ }^{107,113}$ Also reported was contamination with hepatotoxic seeds ${ }^{20}$ as well as heavy metals such as arsenic, mercury, and lead. ${ }^{86,107,113}$ These shortcomings are well recognized ${ }^{1-4}$ and require stringent controls by producers and regulatory agencies. ${ }^{1}$ Analyses for contamination were rarely done, except for the 
herbal mixtures Chaso and Onshido, where contamination with heavy metals like copper, lead, bismuth, cadmium, antimony, tin, mercury, and chromium was not found. ${ }^{27}$ Contaminants also were lacking in Jin Bu Huan. ${ }^{43,44}$ In other Chinese herbal mixtures, aflatoxins, ${ }^{12}$ fungi, ${ }^{12}$ heavy metals, ${ }^{12}$ and PAs were excluded, ${ }^{16}$ but insect fragments (Cryptotympane pustulata) were present in the preparations. ${ }^{12}$ The TCM Hai Piao Xiao (Endoconcha sepiae) and Ling Zhi (Ganoderma lucidum, mushroom) are listed as ingredients of Bai Shi Wan (Table 1). ${ }^{11}$

Even (criminal) adulterations of herbal TCM products with synthetic drugs not declared as such have been published. ${ }^{1,25,91,106,107}$ Analysis for possible adulterants were rarely done and usually negative. ${ }^{43,44}$ Adulteration of the herbal TCM products Chaso and Onshido ${ }^{27}$ and other TCM products ${ }^{14}$ by the synthetic N-nitroso-fenfluramine was found, ${ }^{15,27}$ but its hepatotoxic property has not been established. ${ }^{27,86} \mathrm{~N}$-nitroso-fenfluramine therefore is merely an adulterant that is not related to liver injury ${ }^{86}$ observed in the reported cases. ${ }^{15,27}$ Neither Chaso nor Onshido are registered by the China FDA; but were produced by Chinese manufacturers and exported to Japan until retracted from the market. ${ }^{27}$ Actually, China FDA has established analytical methods and product inspections to provide consumer safety. ${ }^{1}$ Especially for unregistered products, adulteration with chemical compounds remains a problem in China and other countries.

\section{NON HERBAL TCM}

Uncertainty of and concern for hepatotoxicity exists also related to the use of non-herbal TCM elements. ${ }^{15,17,18,25,48,91,114-118}$ They are commonly consumed together with herbal TCM products ${ }^{15,91}$ and occasionally even named identically. ${ }^{91}$ Known or potentially hepatotoxic non-herbal TCM elements are Bai Hua She (venom of the Chinese viper Agkistrodon acutus), ${ }^{15}$ Jiang Can (dried larvae of Bombyx Batryticatus, infected by Batrytis bassiana),${ }^{15}$ Ling Yang Qing Fei (antelope horn), ${ }^{15}$ Liyu Danzhi (carp juice), ${ }^{114}$ Quan Xie (dry polypides of the scorpion Buthus martensii), ${ }^{15}$ Sang Hwang (Phellinus lihnteus, mushroom), ${ }^{17,18}$ Song Rong (Agaricus blazei, Himematsutake as Japanese Kampo Medicine, mushroom), ${ }^{115} \mathrm{Wu}$ Gong (dried polypites of the centipede Scolopendra subspinipes mutilans), ${ }^{15} \mathrm{Wu}$ Shao She (syn. Wu Xiao She, Sheng Wu Shao She, parts of the snake Zaocys dhumnades), ${ }^{15}$ and Yu Dan (fish gallbladder). ${ }^{116-118}$ Details of their adverse properties to date often remain unexplored for some products.

\section{COCHRANE}

The Cochrane Handbook provides some general recommendations related to adverse effects, especially choosing which adverse effects to include, the types of studies, and search methods for adverse effects. ${ }^{119}$ These specifications do not necessarily apply to our short analysis, since we focused only on one single adverse effect and did not choose other adverse types. Our report also was based on single case reports or short case series, not on various types of detailed studies which actually are not available in the scientific literature for further assessment by us and others. Finally, specific search methods for hepatotoxicity cases have already been applied in this analysis, and there is no need for additional refinement.

However, the Cochrane Handbook ${ }^{119}$ was a good basis evaluating and summarizing evidence from the Cochrane Collaboration for traditional Chinese medicine therapies with focus on herbal TCM. ${ }^{120}$ Overall, 70 Cochrane systematic reviews of TCM were identified, including 42 reviews related to herbal TCM, with 22/42 herbal medicine reviews that concluded that there was not enough good quality trial evidence to make any conclusion about the efficacy of the evaluated treatment, while the remaining 20 herbal TCM reviews indicated a suggestion of benefit, which was qualified by a caveat about the poor quality and quantity of studies. Most reviews included many distinct interventions, controls, outcomes, and populations, and a large number of different comparisons were made, each with a distinct forest plot. ${ }^{120}$

Considering these uncertainties of therapeutic efficacy as summarized by the Cochrane reviews for herbal $\mathrm{TCM}^{120}$ and the hepatotoxicity risk of herbal TCM use as outlined in the present study (Table 1), the risk/benefit/ratio is clearly negative.

\section{LIMITATION OF THE ANALYSIS}

Products of herbal TCM commonly are used as TCM dietary supplements or TCM drugs. Product variability and lack of product standardization regarding their ingredients may create uncertainty and scientific discussions. In addition, listed herbs or products might be arguable as having merely a low affinity to TCM. For many TCM mixtures, only the primary pharmacologically active the other component, called the king herb, is mentioned as ingredient,${ }^{6}$ neglecting the other ingredients. This may 
cause some irritation and discussion due to incomplete product specification.

\section{CONCLUSIONS}

Liver injury was reported for 57 different TCM herbs and herbal mixtures. Causality was likely or probable for 28 out of these 57 herbal products based on the CIOMS scale, positive reexposure test results, or both, while the remaining cases often remained unassessable. Thus, further efforts are needed to enhance the quality of causality assessment for future cases of suspected herbal hepatotoxicity by TCM; an objective approach like the CIOMS scale should be applied in all cases.

\section{ACKNOWLEDGEMENT}

The authors declare that they have no conflict on interest.

\section{REFERENCES}

1. Zhang L, Yan J, Liu X, Ye Z, Yang X, Meyboom R, Chan K, et al. Pharmacovigilance practice and risk control of Traditional Chinese Medicine drugs in China: Current status and future perspective. J Ethnopharmacol 2012; 140: 519-25.

2. Tang JL, Liu BY, Ma KW. Traditional Chinese medicine. Lancet 2008; 372: 1938-40.

3. NIH, National Center for Complementary and Alternative Medicine (NCCAM). Traditional Chinese Medicine: An Introduction. Last updated October 2013. Available at: http:// nccam.nih.gov/health/whatiscam/chinesemed.htm [Accessed 7 July, 2014].

4. National Institutes of Health $(\mathrm{NIH})$ and LiverTox: Chinese and other Asian herbal medicines. Last updated 10 January 2013. Available at: http://livertox.nih.gov/ ChineseAndOtherAsianHerbalMedicines.htm [Accessed 7 July, 2014].

5. Ernst E. Review article. Methodological aspects of Traditional Chinese Medicine (TCM). Ann Acad Med Singapore 2006; 35: 773-4.

6. Bunchorntavakul C, Reddy KR. Review article: herbal and dietary supplement hepatotoxicity. Aliment Pharmacol Ther 2013; 37: 3-17.

7. Teschke R, Wolff A, Frenzel C, Schulze J, Eickhoff A. Herbal hepatotoxicity: A tabular compilation of reported cases. Liver Int 2012; 32: 1543-56.

8. Teschke R, Schwarzenboeck A, Eickhoff A, Frenzel C, Wolff A, Schulze J. Clinical and causality assessment in herbal hepatotoxicity. Expert Opin Drug Saf 2013; 12: 330-66.

9. Haller CA, Dyer JE, Ko R, Olson KR. Making a diagnosis of herbal-related toxic hepatitis. West J Med 2002; 176: 39-44.

10. Estes JD, Stolpman D, Olyaei A, Corless CL, Ham JM, Schwartz JM, Orloff S. High prevalence of potentially hepatotoxic herbal supplement use in patients with fulminant hepatic failure. Arch Surg 2003; 138: 852-8.

11. Talari P, Talari G, Gundareddy V, Vemula P, Barmecha J. Acute hepatitis associated with the chinese herbal product bai shi wan. Available at: http://
www.toothpicks.info/rc2/posters/2010/Internal_Medicine/ Talari_P_Acute_hepatitis_associated.pdf [Accessed 7 July, 2014].

12. Perharic-Walton L, Murray V. Toxicity of traditional Chinese herbal remedies. Lancet 1992; 340: 674.

13. Kane JA, Kane SP, Jain S. Hepatitis induced by traditional Chinese herbs: possible toxic components. Gut 1995; 36: 146-7.

14. Vautier G, Spiller RC. Safety of complementary medicines should be monitored. BMJ 1995; 311: 633.

15. Yuen MF, Tam S, Fung J, Wong DKH, Wong BCY, Lai CL. Traditional Chinese Medicine causing hepatotoxicity in patients with chronic hepatitis B infection: a 1-year prospective study. Aliment Pharmacol Ther 2006; 24: 1179-86.

16. Jang JS, Seo EG, Han C, Chae HB, Kim SJ, Lee JD, Wang JH. Four cases of toxic liver injury associated with Dictamnus dasycarpus. Korean J Hepatol 2008; 14: 206-12 (Abstract in English, article in Korean).

17. Kang SH, Kim JI, Jeong KH, Ko KH, Ko PG, Hwang SW, Kim $E M$, et al. Clinical characteristics of 159 cases of acute toxic hepatitis. Korean J Hepatol 2008; 14: 483-4 (Abstract in English, article in Korean).

18. Sohn $\mathrm{CH}$, Cha MI, Oh BJ, Yeo WH, Lee JH, Kim W, Lim KS. Liver transplantation for acute toxic hepatitis due to herbal medicines and preparations. J Korean Soc Clin Toxicol 2008; 6: 110-6 (Abstract in English, article in Korean).

19. Cortez E, Boulger C, Bernard A. Ban Tu Wan hepatotoxicity. BMJ Case Reports 2012. DOI: 10.1136/bcr-2012006438.

20. Sangsuwan C, Udompanthurak S, Vannasaeng S, Thamlikitkul V. Randomized controlled trial of Tinospora crispa for additional therapy in patients with type 2 diabetes mellitus. J Med Assoc Thai 2004; 87: 543-6 (Abstract in English, article in Thai).

21. Motoyama H, Enomoto M, Yasuda T, Fujii H, Kobayashi S, Iwai $\mathrm{S}$, Morikawa $\mathrm{H}$, et al. Drug-induced liver injury caused by a herbal medicine, bofu-tsu-sho-san. Nihon Shokakibyo Gakkai Zasshi 2008; 105: 1234-9 (Abstract in English, article in Japanese).

22. Hwang SH, Park JA, Jang YS, Lee KM, Lee DS, Ahn BM, Lee $\mathrm{EH}$. Case of acute cholestatic hepatitis caused by the seeds of Psoralea-corylifolia. Korean J Hepatol 2001; 7: 341-4 (Abstract in English, article in Korean).

23. Nam SW, Baek JT, Lee DS, Kang SB, Ahn BM, Chung KW. A case of acute cholestatic hepatitis associated with the seeds of Psoralea corylifolia (Boh-Gol-Zhee). Clin Toxicol 2005; 43: 589-91.

24. Cheung WI, Tse ML, Ngan T, Lin J, Lee WK, Poon WT, Mak TW, et al. Liver injury associated with the use of Fructus Psoraleae (Bol-gol-zhee or Bu-gu-zhi) and its related propriety medicine. Clin Toxicol 2009; 47: 683-5.

25. Chau TN. Drug-induced liver injury: an update. Hong Kong Med Diary 2008; 13: 23-6.

26. Lee $\mathrm{CH}$, Wang JD, Chen PC. Risk of liver injury associated with Chinese herbal products containing Radix bupleuri in 639,779 patients with hepatitis B virus infection. PLoS ONE 2011; 6(1): e16064. DOI: 10.1371/journal.pone. 0016064

27. Adachi M, Saito H, Kobayashi H, Horie $Y$, Kato S, Yoshioka $\mathrm{M}$, Ishii $\mathrm{H}$. Hepatic injury in 12 patients taking the herbal loss aids Chaso and Onshido. Ann Intern Med 2003; 139: 488-92.

28. Lin TJ, Tsai MS, Chiou NM, Deng JF, Chiu NY. Hepatotoxicity caused by Breynia officinalis. Vet Hum Toxicol 2002; 44: 87-8. 
29. Lin TJ, Su CC, Lan CK, Jiang DD, Tsai JL, Tsai MS. Acute poisonings with Breynia officinalis - an outbreak of hepatotoxicity. J Toxicol Clin Toxicol 2003; 41: 591-4.

30. Yoshida EM, McLean CA, Cheng ES, Blanc PD, Somberg KA, Ferrell LD, Lake JR. Chinese herbal medicine, fulminant hepatitis, and liver transplantation. Am J Gastroenterol 1996; 91: 2647-8.

31. Kamiyama T, Nouchi T, Kojima S, Murata N, Ikeda T, Sato C. Autoimmune hepatitis triggered by administration of an herbal medicine. Am J Gastroenterol 1997; 92: 703-4.

32. Björnsson ES, Bergmann OM, Björnsson HK, Kvaran RB, Olafsson S. Incidence, presentation and outcomes in patients with drug-induced liver injury in the general population of Iceland. Gastroenterology 2013; 144: 1419-25.

33. Verucchi G, Calza L, Attard L, Chiodo F. Acute hepatitis induced by traditional Chinese herbs used in the treatment of psoriasis. J Gastroenterol Hepatol 2002; 17: 1342-3.

34. Kim SY, Yim HJ, Ahn JH, Kim JH, Kim JN, Yoon I, Kim DI, et al. Two cases of toxic hepatitis caused by arrowroot juice. Korean J Hepatol 2009; 15: 504-9 (Abstract in English, article in Korean).

35. Bae SH, Kim DH, Bae YS, Lee KJ, Kim DW, Yoon JB, Hong $\mathrm{JH}$, et al. Toxic hepatitis associated with Polygoni multiflori. Korean J Hepatol 2010; 16: 182-6 (Abstract in English, article in Korean).

36. Gono Y, Odaguchi H, Hayasaki T, Suzuki K, Oikawa T, Muranushi A, Akahoshi T, et al. Clinical analysis of cases with drug-induced liver injury for Kampo medicine. Kampo Med 2010; 61: 828-33 (Abstract in English, article in Japanese).

37. Linnebur SA, Rapacchietta OC, Vejar M. Hepatotoxicity associated with chinese skullcap contained in Move Free Advanced dietary supplement: two case reports and review of the literature. Pharmacotherapy 2010; 750: 258e-262e.

38. Yang L, Aronsohn A, Hart J, Jensen D. Herbal hepatotoxicity from Chinese skullcap: A case report. World J Hepatol 2012; 4: 231-3.

39. Dhanasekaran R, Owens V, Sanchez W. Chinese skullcap in Move Free arthritis supplement causes drug induced liver injury and pulmonary infiltrates. Case Reports Hepatol 2013. Article ID 965092. DOI: org/10.1155/2013/965092.

40. Kang HS, Choi HS, Yun TJ, Lee KG, Seo YS, Yeon JE, Byun $\mathrm{KS}$, et al. A case of acute cholestatic hepatitis induced by Corydalis speciosa Max. Korean J Hepatol 2009; 15: 51723 (Abstract in English, article in Korean).

41. Jorge OA, Jorge AD. Hepatotoxicity associated with the ingestion of Centella asiatica. Rev Esp Enferm Dig 2005; 97: 115-24.

42. Kim YJ, Ryu SL, Shim JW, Kim DS, Shim JY, Park MS, Jung HL. A pediatric case of toxic hepatitis induced by Hovenia dulcis. Pediatr Gastroenterol Hepatol Nutr 2012; 15: 111-6.

43. Woolf GM, Petrovic LM, Rojter SE, Wainwright S, Villamil FG, Katkov WN, Michieletti P, et al. Acute hepatitis associated with the Chinese herbal product Jin Bu Huan. Ann Intern Med 1994; 121: 729-35.

44. Horowitz RS, Feldhaus K, Dart RC, Stermitz FR, Beck JJ. The clinical spectrum of Jin Bu Huan toxicity. Arch Intern Med 1996; 156: 899-903.

45. Picciotti A, Campo N, Brizzolara R, Giusto R, Guido G, Sinelli N, Lapertosa G, et al. Chronic hepatitis induced by Jin Bu Huan. J Hepatol 1998; 28: 165-7.

46. Divinsky M. Case report: Jin Bu Huan - not so benign herbal medicine. Can Fam Physician 2002; 48: 1640-2.

47. Inoue H, Yamazaki S, Shimizu M, Uozki H, Goto T, Ohnishi S, Koike K. Liver injury induced by the Japanese herbal drug kamishoyosan. Gastroenterol Hepatol 2011: 7: 692-5.
48. Garcia-Moran S, Saez-Royuela F, Gento E, Lopez Morante A, Arias L. Acute hepatitis associated with Camellia tea and Orthosiphon stamineus ingestion. Gastroenterol Hepatol 2004; 27: 559-60.

49. Peyrin-Biroulet L, Petitpain N, Kalt P, Ancel D, Petit-Laurent $\mathrm{F}$, Trechot $\mathrm{P}$, Barraud $\mathrm{H}$, et al. Probable hepatotoxicity from epigallocatecol gallate used for phytotherapy. Gastroenterol Clin Biol 2004; 28: 404-6 (Article in French).

50. Gloro R, Hourmand-Ollivier I, Mosquet B, Mosquet L, Rousselot $P$, Salamé $E$, Piquet MA, et al. Fulminant hepatitis during self-medication with hydroalcoholic extract of green tea. Eur J Gastroenterol Hepatol 2005; 17: 1135-7.

51. Javaid A, Bonkovsky HL. Hepatotoxicity due to extracts of Chinese green tea (Camellia sinensis): a growing concern. J Hepatol 2006; 45: 334-5.

52. Jimenez-Saenz M, Martinez-Sanchez M del C. Acute hepatitis associated with the use of green tea infusions. $J$ Hepatol 2006; 44: 616-7.

53. Bonkovsky HL. Hepatotoxicity associated with supplements containing Chinese green tea (Camellia sinensis). Ann Intern Med 2006: 144: 68-71. Erratum in: Ann Intern Med 2006; 144: 380.

54. Molinari M, Watt KD, Kruszyna T, Nelson R, Walsh M, Huang WY, Nashan B, et al. Acute liver failure induced by green tea extracts: case reports and review of the literature. Liver Transpl 2006; 12: 1892-5.

55. Björnsson E, Olsson R. Serious adverse liver reactions associated with herbal weight loss supplements. J Hepatol 2007; 47: 295-7.

56. García-Cortés M, Borraz Y, Lucena MI, Peláez G, Salmerón $J$, Diago M, Martínez-Sierra MC, et al. Liver injury induced by "natural remedies": an analysis of cases submitted to the Spanish Liver Toxicity Registry. Rev Esp Enferm Dig 2008; 100: 688-95.

57. Sarma DN, Barrett ML, Chavez ML, Gardiner P, Ko R, Mahady GB, Marles RJ, et al. Safety of green tea extract: a systematic review by the US Pharmacopeia. Drug Saf 2008; 31: 469-84.

58. Mazzanti G, Menniti-Ippolito F, Moro PA, Cassetti F, Raschetti R, Santuccio C, Mastrangelo S. Hepatotoxicity from green tea: a review of the literature and two unpublished cases. Eur J Clin Pharmacol 2009; 65: 331-41.

59. Rohde J, Jacobsen C, Kromann-Andersen H. Toxic hepatitis triggered by green tea. Ugeskr Laeger 2011: 173: 205-206 (Abstract in English, article in Danish).

60. Navarro VJ, Bonkovsky HL, Hwang SI, Vega M, Barnhart H, Serrano J. Catechins in dietary supplements and hepatotoxicity. Dig Dis Sci 2013; 58: 2682-90.

61. Nadir A, Agrawal S, King PD, Marshall JB. Acute hepatitis associated with the use of a Chinese herbal product, mahuang. Am J Gastroenterol 1996; 91: 1436-8.

62. Borum ML. Fulminant exacerbation of autoimmune hepatitis after the use of Ma Huang. Am J Gastroenterol 2001; 96: 1654-5.

63. Skoulidis F, Alexander GJ, Davies SE. Ma huang associated acute liver failure requiring liver transplantation. Eur $J$ Gastroenterol Hepatol 2005; 17: 581-4.

64. Reuben A, Koch DG, Lee WM, and the Acute Liver Failure Study Group. Drug-induced acute liver failure: Results of a U.S. multicenter, prospective study. Hepatology 2010; 52: 2065-76.

65. Culvenor CCJ, Edgar JA, Smith LW, Kumana CR, Lin HJ. Heliotropium lasiocarpum Fisch and Mey identified as cause of veno-occlusive disease due to herbal tea. Lancet 1986; 1(8487): 978 . 
66. Aiba T, Takahashi T, Suzuki K, Okoshi S, Nomoto M, Uno K, Aoyagi $Y$. Liver injury induced by a Japanese herbal medicine, sairei-to (TJ-114, Bupleurum and Hoelen combination, Chai-Ling-Tang). J Gastroenterol Hepatol 2007; 22: 762-3.

67. Tsuda T, Yashiro S, Gamo Y, Watanabe K, Hoshino T, Oikawa T, Hanawa T. Discrepancy between clinical course and drug-induced lymphocyte stimulation tests in a case of saireito-induced liver injury accompanied by Sjögren syndrome. J Altern Complement Med 2010; 16: 501-5.

68. Dai HF, Gao Y, Yang M, Yu CH, Gu ZY, Chen WX. Hepatic veno-occlusive disease induced by Gymura segetum: report of two cases. Hepatobiliary Pancreat Dis Int 2006; 5: 406-8.

69. Chen MY, Cai JT, Du Q. Hepatic veno-occlusive disease associated with the use of Gynura segetum. Eur J Intern Med 2007; 18: 609.

70. Li C, Liang XS, Li CZ. Sinusoidal obstruction syndrome associated with the ingestion of gynura root. Clin Toxicol 2010; 48: 962-4.

71. Lin G, Wang JY, Li N, Li M, Gao H, Ji Y, Zhang F, et al. Hepatic sinusoidal obstruction syndrome associated with consumption of Gynura segetum. J Hepatol 2011; 54: 666-73.

72. Gao H, Li N, Wang JY, Zhang SC, Lin G. Definitive diagnosis of hepatic sinusoidal obstruction syndrome induced by pyrrolizidine alkaloids. J Dig Dis 2012; 13: 33-9.

73. Cárdenas A, Restrepo JC, Sierra F, Correa G. Acute hepatitis due to shen-min: a herbal product derived from Polygonum multiflorum. J Clin Gastroenterol 2006; 40: 629-32.

74. But PPH, Tomlinson B, Lee KL. Hepatitis related to the Chinese medicine Shou-wu-pian manufactured from Polygonum multiflorum. Vet Hum Toxicol 1996; 38: 280-2.

75. Park GJH, Mann SP, Ngu MC. Acute hepatitis induced by Shou-Wu-Pian, a herbal product derived from Polygonum multiflorum. J Gastroenterol Hepatol 2001; 16: 115-7.

76. Battinelli L, Daniele C, Mazzanti G, Mastroianni CM, Lichtner M, Coletta S, Costantini S. New case of acute hepatitis following the consumption of Shou Wu Pian, a Chinese herbal product derived from Polygonum multiflorum. Ann Intern Med 2004; 140: 587-8.

77. Panis B, Wong DR, Hooymans PM, De Smet PAGM, Rosias PR. Recurrent toxic hepatitis in a Caucasian girl related to the use of Shou-Wu-Pian, a Chinese herbal preparation. $J$ Pediat Gastroenterol Nutr 2005; 41: 256-8.

78. Laird AR, Ramchandani N, deGoma EM, Avula B, Khan IA, Gesundheit N. Acute hepatitis associated with the use of an herbal supplement (Polygonum multiflorum) mimicking iron-overload syndrome. Clin Gastroenterol 2008; 42: 861-2.

79. Furukawa M, Kasajima S, Nakamura Y, Shouzushima M, Nagatani N, Takinishi A, Taguchi A, et al. Toxic hepatitis induced by Show-Wu-Pian, a Chinese herbal preparation. Inter Med 2010; 49: 1537-40.

80. Valente G, Sanges M, Campione S, Bellevicine C, De Franchis G, Sollazzo R, Matera D, et al. Herbal hepatotoxicity: a case of difficult interpretation. Eur Rev Med Pharmacol Sci 2010; 14: 865-70.

81. Jung KA, Min HJ, Yoo SS, Kim HJ, Choi SN, Ha CY, Kim HJ, et al. Drug-induced liver injury: Twenty five cases of acute hepatitis following ingestion of Polygonum multiflorum Thun. Gut Liver 2011; 5: 493-9.

82. Banarova A, Koller T, Payer J. Toxic hepatitis induced by Polygonum multiflorum. Vnitr Lek 2012; 58: 958-62 (Abstract in English, article in Slovak).
83. Cohen SM, Heywood E, Pillai A, Ahn J. Hepatotoxicity associated with the use of White Flood, a nutritional supplement. Practical Gastroenterology 2012; October issue: $45-8$.

84. Itoh S, Marutani K, Nishijima T, Matsuo S, Itabashi M. Liver injuries induced by herbal medicine, Syo-saiko-to (xiao-chai-hu-tang). Dig Dis Sci 1995; 40: 1845-8.

85. Hsu LM, Huang YS, Tsay SH, Chang FY, Lee SD. Acute hepatitis induced by Chinese hepatoprotective herb xiaochai-hu-tang. J Chin Med Assoc 2006; 69: 86-8.

86. Teschke R. Traditional Chinese Medicine induced liver injury. J Clin Translat Hepatol 2014; 2: 80-94. DOI: 10.14218/JCTH.2014.00003.

87. Teschke R, Wolff A, Frenzel C, Schulze J. Review article: herbal hepatotoxicity - an update on traditional Chinese medicine preparations. Aliment Pharmacol Ther 2014; 40: $32-50$.

88. Davies EG, Pollock I, Steel HM. Chinese herbs for eczema. Lancet 1990; 336: 117.

89. Graham-Brown R. Toxicity of Chinese herbal remedies. Lancet 1992; 340: 673.

90. Sanders D, Kennedy N, McKendrick MW. Monitoring the safety of herbal remedies: Herbal remedies have a heterogeneous nature. Br Med J 1995; 311: 1569.

91. Shaw D. Toxicological risks of Chinese herbs. Planta Med 2010; 76: 2012-8.

92. Pharmacopoeia of the People's Republic of China, Vol. 1. Beijing: Peoples Medical Publishing House; 2005.

93. Chan K. Chinese medicinal materials and their interface with Western medical concepts. J Ethnopharmacol 2005; 96: 1-18.

94. Danan G, Bénichou C. Causality assessment of adverse reactions to drugs - I. A novel method based on the conclusions of international consensus meetings: application to drug-induced liver injuries. J Clin Epidemiol 1993; 46: 1323-30.

95. Teschke R, Frenzel C, Schulze J, Eickhoff A. Herbal hepatotoxicity: challenges and pitfalls of causality assessment methods. World J Gastroenterol 2013; 19: 2864-82.

96. Teschke R, Wolff A, Frenzel C, Schwarzenboeck A, Schulze J, Eickhoff A. Drug and herb induced liver injury: Council for International Organizations of Medical Sciences scale for causality assessment. World J Hepatol 2014; 6: 17-32.

97. Aithal GP, Watkins PB, Andrade RJ, Larrey D, Molokhia M, Takikawa $\mathrm{H}$, Hunt $\mathrm{CM}$, et al. Case definition and phenotype standardization in drug-induced liver injury. Clin Pharmacol Ther 2011; 89: 806-15.

98. National Institutes of Health $(\mathrm{NIH})$ and LiverTox: Drug record. Ba Jiao Lian (Dysosma pleianthum). Last updated 10 September 2013. Available at: http:// livertox.nih.gov/BaJiaoLian.htm [Accessed 7 May, 2014].

99. Teschke R, Genthner A, Wolff A, Frenzel C, Schulze J, Eickhoff A. Herbal hepatotoxicity: Analysis of cases with initially reported positive reexposure tests. Dig Liv Dis 2014; 46: 264-9.

100. Bénichou C. Criteria of drug-induced liver disorders. Report of an international consensus meeting. J Hepatol 1990; 11: 272-6.

101. Takikawa H. A proposal of the diagnostic scale of druginduced liver injury. Hepatology Res 2005; 32: 250-1.

102. Chau TN, Cheung WI, Ngan T, Lin J, Lee KWS, Poon WT, Leung VKS, et al., and the Hong Kong Herb-Induced Liver Injury Network (HK-HILIN). Causality assessment of herb-induced liver injury using multidisciplinary approach and the Roussel Uclaf Causality Assessment Method (RUCAM). Clin Toxicol 2011; 49: 34-9. 
103. Teschke R, Frenzel C, Schulze J, Schwarzenboeck A, Eickhoff A. Herbalife hepatotoxicity: Evaluation of cases with positive reexposure tests. World J Hepatol 2013; 5: 353-63.

104. Teschke R, Frenzel C, Glass X, Schulze J, Eickhoff A. Herbal hepatotoxicity: A critical review. Br J Clin Pharmacol 2013; 75: 630-6.

105. Teschke R, Lebot V. Proposal for a Kava Quality Standardization Code. Food Chem Toxicol 2011; 49: 2503-16.

106. Ernst E. Adulteration of Chinese herbal medicines with synthetic drugs: a systematic review. J Intern Med 2002; 252: 107-13.

107. Posadzki P, Watson L, Ernst E. Contamination and adulteration of herbal medicinal products (HMPs): an overview of systematic reviews. Eur J Clin Pharmacol 2013; 69: 295-307.

108. National Institutes of Health $(\mathrm{NIH})$ and LiverTox: Drug record. Chi R Yun (Breynia officinalis). Last updated 25 October 2013. Available at: http://livertox.nih.gov/ ChiRYun.htm [Accessed 7 July, 2014].

109. Wu GL, Yu GY, Chen J. Clinical analysis of hepatic venoocclusive disease induced by Sedum aizoon. Zhongguo Zhong Yao Za Zhi 2008; 33: 2402-4 (Abstract in English, article in Chinese).

110. Wang JY, Gao H. Tusanqi and hepatic sinusoidal obstruction syndrome. Dig Dis 2014; 15: 105-7.

111. Kumana CR, Ng M, Lin HJ, Ko W, Wu PC, Todd D. Herbal tea induced hepatic veno-occlusive disease: quantification of toxic alkaloid exposure in adults. Gut 1985; 26: $101-4$.
112. Kumana CR, Ng M, Lin HJ, Ko W, Wu PC, Todd D. Hepatic veno-occlusive disease due to toxic alkaloid in herbal tea. Lancet 1983; II: 1360-1.

113. Ko RJ. Adulterants in Asian patent medicines. $N$ Engl $J$ Med 1998; 339: 847.

114. Son HS, Kim GS, Lee SW, Kang SB, Back JT, Nam SW, Lee DS, et al. Toxic hepatitis associated with carp juice ingestion. Korean J Hepatol 2006; 12: 103-6 (Abstract in English, article in Korean).

115. Mukai H, Watanabe $\mathrm{T}$, Ando $\mathrm{M}$, Katsumata N. An alternative medicine, Agaricus blazei, may have induced severe hepatic dysfunction in cancer patients. Jpn J Clin Oncol 2006; 36: 808-10.

116. Chan DWS, Yeung CK, Chan MK. Acute renal failure after eating raw fish gall bladder. BMJ 1985: 295: 897.

117. Xuan BHN, Thi TXN, Nguyen ST, Goldfarb DS, Stokes MB, Rabenou RA. Ichthyotoxic ARF after fish gallbladder ingestion: a large case series from Vietnam. Am J Kidney Dis 2003; 41: 220-4.

118. Kung SW, Chan YC, Tse ML, Lau FL, Chau TL, Tam MKP. Acute renal failure and hepatitis following ingestion of carp gallbladder. Clin Toxicol 2008; 46: 753-7.

119. Higgins JPT, Green S (eds.). Cochrane Handbook for Systematic Reviews of Interventions (Cochrane Book). Wiley Blackwell, Chiester, West Sussex, England; 2008.

120. Manheimer E, Wieland S, Kimborough E, Cheng K, Berman BM. Evidence from the Cochrane Collaboration for traditional Chinese medicine therapies. J Alternat Complement Med 2009; 15: 1001-4. 